\title{
БИОЛОГИЧЕСКАЯ АКТИВНОСТЬ НЕКОТОРЫХ БЕНЗОФУРАНОВ
}

\author{
Г.Н. Сахабутдинова, Г.З. Раскильдина, С.С. Злотский \\ Уфимский государственный нефтяной технический университет, \\ 450064, Россия, Уфа, Космонавтов, 1.
}

DOI: 10.19163/MedChemRussia2021-2021-504

E-mail: gulya06111992@mail.ru

Производные бензофуранов проявляют разнообразную биологическую активность (противобактериальную, противогрибковую, противовоспалительную), тем самым они привлекают внимание, как перспективные соединения для получения лекарственных препаратов на их основе [1,2].

В настоящей работе нами были получены бензофураны взаимодействием замещенных фенолов 2-7 с этил-2-диазо-3-оксобутаноатом 1 в присутствии Сu(OTf). Реакция протекает по связи О-Н фенолов с образованием O-арилалкоксикарбонилкетонов, которые далее под действием полифосфорной кислоты (РPA) циклизуются в бензофураны.

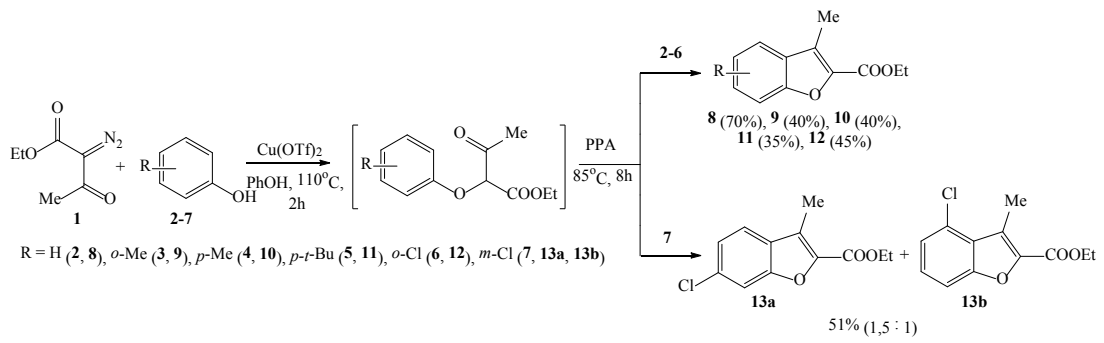

Стоит отметить, что в случае мета-хлорфенола 7 в реакционной массе присутствуют оба изомерных бензофурана 13a и 13b в соотношении 1,5:1.

Была изучена противомикробная активность полученных бензофуранов против штаммов микроорганизмов: Escherichia coli (грамотрицательные палочки), Staphylococcus aureus (грамположительные кокки), Bacillus cereus (грамположительные спорообразующие палочки) и низших грибов - Candida albicans. Установлено, что среди полученных бензофуранов, соединения 13a,b проявили наибольшую противомикробную активность.

«Исследования выполнены при финансировании гранта Президента РФ для

государственной поддержки молодых российских ученых - кандидатов наук и докторов наук по № MK-1689.2020.3».

\section{Литература}

[1] R.M. Sultanova, M.D. Khanova, V.A. Dokichev, ARKIVOC. 2009, 236-247.

[2] Г.Н. Шайхуллина, Р.М. Султанова, И.П. Байкова, Р.З. Раскильдина, С.С. Злотский, Изв. АН. Сер. хим., 2017, 1, 164-167. 